\title{
Isolation and Screening of Protease Producing Bacteria from Local Environment for Detergent Additive
}

\author{
Temam Abrar Hamza \\ Department of Biotechnology, College of Natural Sciences, Arba Minch University, Arba Minch, Ethiopia
}

Email address:

temam2abrar2@gmail.com

\section{To cite this article:}

Temam Abrar Hamza. Isolation and Screening of Protease Producing Bacteria from Local Environment for Detergent Additive. American Journal of Life Sciences. Vol. 5, No. 5, 2017, pp. 116-124. doi: 10.11648/j.ajls.20170505.11

Received: June 15, 2017; Accepted: June 23, 2017; Published: August 30, 2017

\begin{abstract}
Proteases are among the most important hydrolytic enzymes that found in every organism to undertake important physiological functions. They are multipurpose enzymes used in various industries such as detergent, silver recovery, food, pharmaceutical, leather, and textile industries. This work aimed to produce protease from indigenous microbes for use as detergent additive. Isolation of protease producer was undertaken using skim milk agar medium. Crude enzyme was characterized in terms of wash and stain removal tests. A total of 188 protease positive bacteria were isolated from seven samples collected from Arba Minch town. Out of 36 alkaline protease producing bacteria, one isolate designated as Bacillus sp. $\mathrm{Cab} 44$ was selected. The optimum activity was reached at $\mathrm{pH} 9$ and $50^{\circ} \mathrm{C}$. The enzyme was stable in the $\mathrm{pH}$ range of 7 to 10 . It retained $75 \%, 86 \%$ and $72 \%$ activity after one $\mathrm{hr}$ pre-incubation at $50^{\circ} \mathrm{C}$, in $15 \% \mathrm{H}_{2} \mathrm{O}_{2}$ and $0.3 \%$ commercial detergent respectively. The enzyme activity was increased by $\mathrm{Mg}^{2+}, \mathrm{Cu}^{2+}$, and $\mathrm{Mn}^{2+}$, was not affected by $\mathrm{Ca}^{2+}$ but decreased by $\mathrm{Zn}^{2+}$, $\mathrm{Hg}^{2+}$ and $\mathrm{Fe}^{2+}$. It removed stains of blood and egg yolk on cotton cloth at $\mathrm{pH} 9,40^{\circ} \mathrm{C}, 5.07 \mathrm{U} / \mathrm{ml}$ in $30-40$ min. These properties suggest that protease from Bacillus sp. Cab44 could find potential application in detergent industries as good candidate of additive in detergent formulation which have economic implication.
\end{abstract}

Keywords: Bacillus sp. Cab44, Detergent Additive, Enzyme, Protease

\section{Introduction}

Proteases are among the most important hydrolytic group of enzymes that found in every organism (prokaryotes, fungi, plants and animals) to undertake important physiological functions [1]. Modern science (microbial biotechnology) explores and exploits the beneficial microbial wealth for various human requirements. Humans over the ages have been highly successful in applying processes carried out by microorganisms to solve problem in various industry and environmental quality. Although, animal and plant proteases are of important industrial applications, a large proportion of commercially useful proteolytic enzymes currently available in the market are from microorganisms [2].

Microbial proteases are one of the most important groups of enzymes, used in various industrial processes as food, pharmaceutical and detergent industries, as well as in the preparation of leather, textile and wool, among others [3, 4, 5, $6]$. It has also promising application in medical usage and management of industrial and household waste. The use of microbial system (enzymes) is the best alternative for generation of pollution free industries.

The idea of using detergent enzymes dates back to 1914 when two German scientists, Rohm and Haas, used pancreatic proteases and sodium carbonate in washing detergents. However, it was only in 1963 alkaline protease was effectively incorporated in detergent powder. Due to this its economic importance became well known [7]. However, currently proteases constitute the largest product segment in the global industrial enzymes market. The detergent enzyme market has grown nearly 10 -fold during the past 20 years [8].

Removal of proteinaceous stains such as blood, milk, egg, grass and chocolate is very difficult using conventional detergent method. However, removal of such stain is achieved by using alkaline proteases $[9,10,11]$. In addition the use of protease supplementation to detergent formulation significantly improves the cleansing of proteinaceous stain and to deliver unique benefits that cannot otherwise be obtained with conventional detergent technologies [12, 13]. 
Over the past 30 years, the proteases in detergents have changed from being minor additives to being the key ingredients.

Most commercially available detergents have an alkaline $\mathrm{pH}$ and contain chelating agents to overcome water hardness. As result enzyme used for detergent application need to be active and stable at alkaline $\mathrm{pH}$, ionic strength of detergent solution, different washing temperature range $\left(25-60^{\circ} \mathrm{C}\right)$. There are also many more parameters involved in the selection of a good detergent protease, such as compatibility with detergent components, e.g. surfactants, perfumes and bleaches; stain degradation and shelf life [3, 7]. Good detergent enzyme should also be stable in the presence of oxidizing agents and bleaches.

Despite the vast microbial diversity of Ethiopia, alkaline protease producing bacteria have not yet been explored. Therefore a research project has been initiated to investigate alkaline protease from bacteria isolated from local habitat and examine their potential to be used as detergent additives.

\section{Materials and Methods}

\subsection{Materials}

The major instruments used in this study were Spectrophotometer, incubator, autoclave, micropipette, rotary shaker and water bath shaker. The major chemicals used were Folin Ciocalteau's phenol reagent, different buffers, hydrogen peroxide, $\mathrm{HCl} \mathrm{NaOH}$, Casein and trichloroacetic acid.

\subsection{Methods}

\subsubsection{Sample Collection and Isolation of Alkalophilic and Proteolytic Bacteria}

Samples were collected from different environments around Arba Minch like abattoir, waste disposing area, fish processing area, compost processing site, Abaya and Chamo Lakes. Each sample was kept in clean sterile sample bottles sealed and transferred to the laboratory and stored at $7^{\circ} \mathrm{C}$.

The soil and water samples were suspended in water by vigorous vortexing and serial dilutions were made up to $10^{-6}$ in sterile distilled water. $0.1 \mathrm{ml}$ of appropriate dilution were added to petri plate on skim milk agar plate containing peptone $(0.1 \%), \mathrm{NaCl}(0.5 \%)$, Agar (2\%) and skimmed milk $(10 \%)$ at $\mathrm{pH} 9$ and incubated at $40^{\circ} \mathrm{C}$ for three days. Alkaliphilic proteolytic bacteria were screened. A clear zone formed colonies at $\mathrm{pH} 9$ were picked and purified by streaking on skim milk agar. The cultures were subsequently sub-cultured and used regularly. Agar slants were prepared and preserved at $7{ }^{\circ} \mathrm{C}$ for further experiments and in $25 \%$ glycerol stocks at $-25^{\circ} \mathrm{C}$ for long term storage.

\subsubsection{Screening of Potential Isolates}

Five alkalophilic strains were screened on the basis of clear zone size for further selection of single isolate on the quality of enzyme produced under submerged condition. The supernatant from each isolate was used as crude enzyme for observing individual wash performance. Isolate which had high potential on egg stain removal efficiency were selected for further characterization. Finally colonial morphology, cellular morphology and biochemical characteristics were undertaken. Identification of the selected potential isolate was done according to Bergey's manual of determinative bacteriology. Colony morphology characterized by direct observation of the overnight grown microorganisms on skim milk agar plate.

\subsubsection{Production of Protease, Protease Assay and Enzyme Unit $(U / m l)$}

Protease production media containing $(\mathrm{g} / \mathrm{l})$ : Glucose 10 , Peptone 7.5, $\mathrm{MgSO}_{4} 7 \mathrm{H}_{2} \mathrm{O} 5, \mathrm{~K}_{2} \mathrm{HPO}_{4} 2, \mathrm{CaCl} 1$ [14] was prepared for enzyme production. The $\mathrm{pH}$ of the medium was adjusted to 9 . The bacterial isolate was inoculated with $1 \%$ of inoculum into $250 \mathrm{ml}$ Erlenmeyer flasks containing $100 \mathrm{ml}$ production medium followed by incubation at $30^{\circ} \mathrm{C}$ for 48 hours in rotary shaker at $150 \mathrm{rpm}$. Culture filtrates were separated by centrifugation at $5000 \mathrm{rpm}$ for $15 \mathrm{~min}$ and the supernatants were used as crude enzyme source for quantitative enzyme assay.

Protease activity in the culture supernatant was determined using casein as a substrate with some modification of the method described by Gaur et al. (2010) [15]. The enzyme activity was expressed in units (U) and calculated by using tyrosine standard calibration curve. One unit of enzyme was defined as the amount of enzyme that releases $1 \mu \mathrm{mol}$ of tyrosine per $\mathrm{ml}$ of crude extract per minute under standard conditions at $40^{\circ} \mathrm{C}$. The tyrosine standard curve was used to generate the enzyme unit determination formula in $\mathrm{U} / \mathrm{ml}$.

\subsubsection{Characterization of Crude Enzyme}

The protease activity of crude enzyme at different $\mathrm{pH}$ value was tested with $0.005 \mathrm{M}$ sodium bicarbonate buffer $(\mathrm{pH}$ 7.0 to 10.0$)$ and $0.02 \mathrm{M}$ potassium chloride $/ \mathrm{NaOH}$ buffer $(\mathrm{pH}$ 11.0 to 12.0$)$. $\mathrm{pH}$ stability was determined by preincubating the crude supernatant in buffers of $\mathrm{pH}(7-12)$ for $1 \mathrm{hr}$. The enzyme activity was measured at $40^{\circ} \mathrm{C}$.

Temperature effect on protease activity was determined at different temperatures $\left(30-70^{\circ} \mathrm{C}\right)[16]$. To determine thermal stability, the samples were pre-incubated at different temperatures $\left(45\right.$ and $\left.50^{\circ} \mathrm{C}\right)$ following determination of residual activity every 20 minutes. Relative protease activity (expressed in\%) was defined as the percent protease activity compared with the maximum value.

To investigate the effect of oxidizing agents on enzyme stability, hydrogen peroxide was used from $0-30 \%$ in the reaction mixture. Pre-incubation of the reaction mixtures was carried out by mixing equal amount of enzyme and $\mathrm{H}_{2} \mathrm{O}_{2}$ [17].

To determine the effect of metal ions on enzyme activity, the enzyme assay was carried out in the presence of $0.01 \mathrm{M}$ $\mathrm{CaCl}_{2}, \mathrm{MgSO}_{4}, \mathrm{FeSO}_{4}, \mathrm{ZnCl}_{2}, \mathrm{MnSO}_{4}, \mathrm{HgCl}_{2}$ and $\mathrm{CuSO}_{4}$. The activity of the enzyme without any additives was taken as $100 \%$. 


\subsubsection{Stain Removal and Detergent Compatibility of Crude Enzyme}

A commercial powder detergent, Aerial was used for detergent compatibility test of enzyme produced by the selected isolate. The detergent was heated at $100^{\circ} \mathrm{C}$ for $1 \mathrm{hr}$ to denature all enzymes found in the detergent [18]. Crude enzyme was preincubated with $0.3 \%(\mathrm{w} / \mathrm{v})$ heated detergent for $1 \mathrm{hr}$ and residual activity was measured to check the compatibility of the enzyme with all the surfactants found in the detergent. Enzyme without detergent was used as a control.

Wash test with protease preparation: Wash performance of crude enzyme was determined according to the method of Pathak and Deshmukh (2012) [18] with little modification. White test fabric (cotton) cloth piece $(5 \times 5 \mathrm{~cm})$ stained with animal blood or egg yolk was allowed to dry in open air for 5 $\mathrm{hr}$. The stained cloth was put in petri dish and treated with 10 $\mathrm{ml}$ crude enzyme at $40^{\circ} \mathrm{C}$ for $30-40 \mathrm{~min}$. Phosphate buffer was used as control under the same condition. Protein stain removal was checked qualitatively by visualization.

\subsection{Experimental Design and Statistical Analysis}

Average values of duplicate experiments were taken. Microsoft office Excel worksheet 2010 was used for data analysis and presentation.

\section{Results}

\subsection{Isolation of Alkalophilic and Proteolytic Bacteria}

One hundred eighty eight protease positive isolates were obtained from seven sample areas 61, 20, 11, 38, 22, 13 and 23 from Abaya Lake, Chamo Lake, AMU soil, compost processing site, abattoir, waste disposing area and fish processing area respectively. Hence the strains were identified as a protease producer (Figure 1). Out of 188, 36 alkaline protease positive bacterial isolates were screened and five isolates with relatively higher clear zones were further examined.

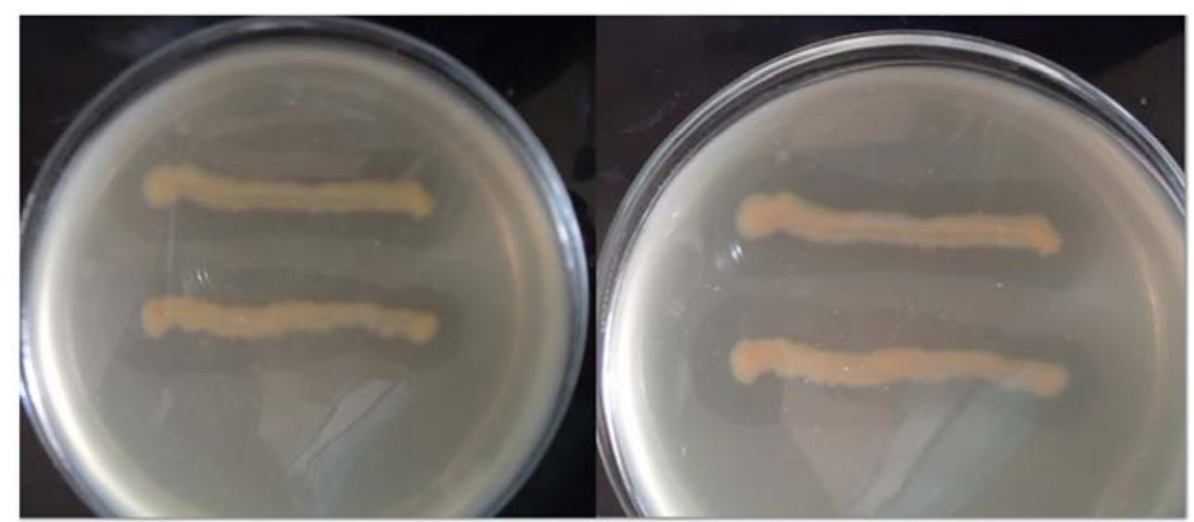

Figure 1. Zone of hydrolysis by strain Cab44 in milk agar plate after $24 \mathrm{~h}$ incubation at $40^{\circ} \mathrm{C}$.

Among the five isolates, one potential isolate with high egg yolk stain removal efficiency from cloths were selected for further characterization. The results are summarized in Table 1.

Table 1. Results of stain removal efficiency of five selected isolates.

\begin{tabular}{llll}
\hline Sample Area & Strain code & Egg yolk stain removal efficiency & Remark \\
\hline- & Control & Before Treatment \\
AMU Soil & Cam5 & \\
Fish Processing Area & Cfp10 & After Treatment \\
Abaya Lake & Cal16 & \\
Chamo Lake & Cc133 \\
& Cab44 \\
\hline
\end{tabular}




\subsection{Morphological and Biochemical Characteristics of Isolate Cab44}

Table 2 shows results of morphological and biochemical tests of the selected isolate. The isolate was characterized as Gram positive and catalase positive. The colonies were

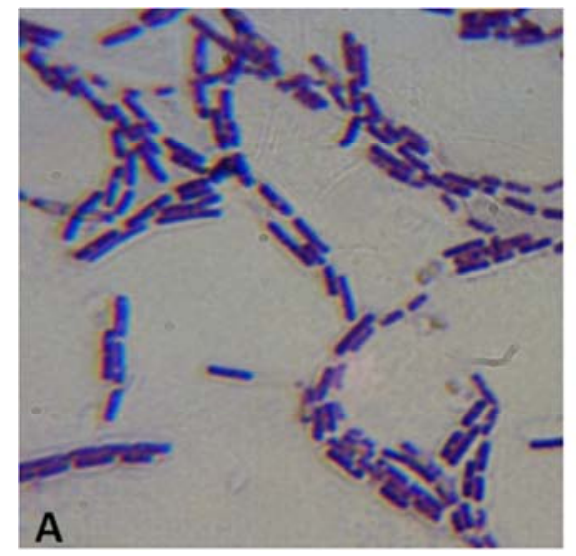

characterized as opaque, irregular and spready configuration and irregular margin. Motile, long irregular and rod shaped cells were observed under light microscope with $1000 \mathrm{X}$ magnification. The strain was able to hydrolyse casein. Based on this the isolate was designated as Bacillus sp. Cab44.

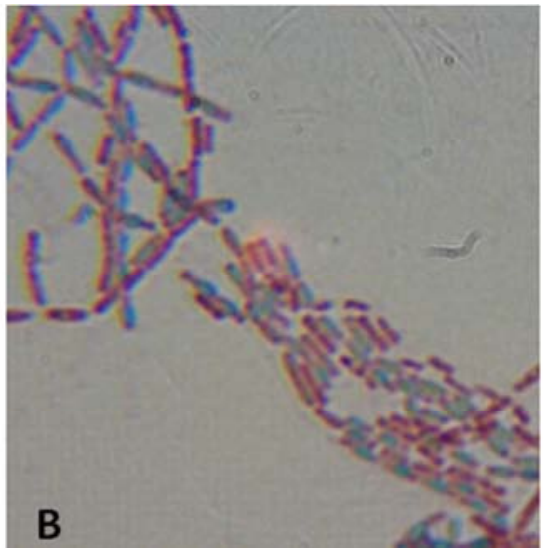

Figure 2. Gram reaction result (+ve) (a) and Endospore of Bacillus sp. Cab44 (b) at $40^{\circ} \mathrm{C}$ and $24 \mathrm{~h}$ on milk agar.

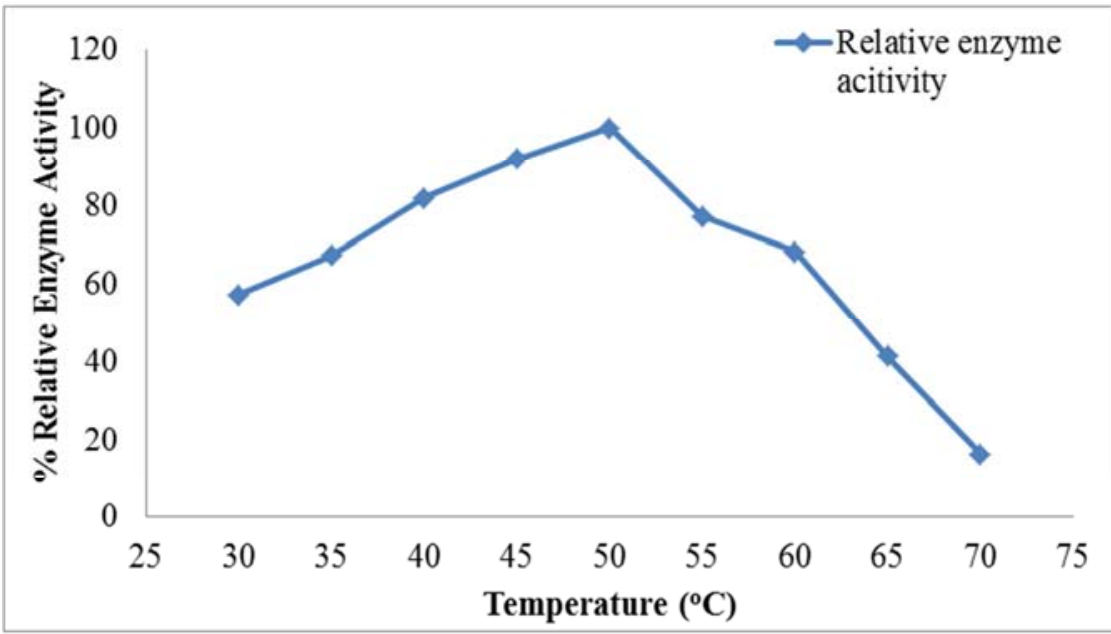

Figure 3. Effect of temperature on enzyme activity after 30 min incubation at different temperature.

Table 2. Results of the morphological and biochemical tests of isolate Cab44.

\begin{tabular}{ll}
\hline Morphological characteristics & Results \\
\hline Colour & Creamy white \\
Size & Large \\
Margin & Irregular \\
Elevation & Flat \\
Configuration & Irregular and spread \\
Morphology & Rod \\
Optical density & Opaque \\
Gram reaction & Positive \\
Endospore & Elliptical \\
Motility test & positive \\
Biochemical and physiological characteristics & Results \\
Nitrate reduction & Negative \\
Indole tests & Positive \\
MR-VP test & Negative \\
Citrate utilization & Negative \\
Casein hydrolysis & Positive \\
\hline
\end{tabular}

\subsection{Characterization of Crude Enzyme}

3.3.1. Effect of Temperature on Enzyme Activity and Stability

The protease produced from Bacillus sp. Cab44 was found to be active at a range of temperatures, between 30 and $60^{\circ} \mathrm{C}$. Figure 3 shows that maximum enzyme activity was recorded at $50^{\circ} \mathrm{C}$ and the enzyme retained $16 \%$ of its maximum activity at $70^{\circ} \mathrm{C}$. Around $80 \%$ of its maximum activity was expressed at 40 and $55^{\circ} \mathrm{C}$.

The enzyme was stable at 45 and $50^{\circ} \mathrm{C}$ retaining more than $90 \%$ and $75 \%$ of its maximum activity for $60 \mathrm{~min}$ of preincubation respectively.

\subsubsection{Effect of pH on Enzyme Activity and Stability}

The enzyme was active in the range of $\mathrm{pH} 7-11$ as shown in Figure 5. The optimum activity $\mathrm{pH}$ was 9.0. The enzyme showed $89 \%$ and $82.1 \%$ of its maximum activity at $\mathrm{pH} 8.0$ and 10.0 respectively. 


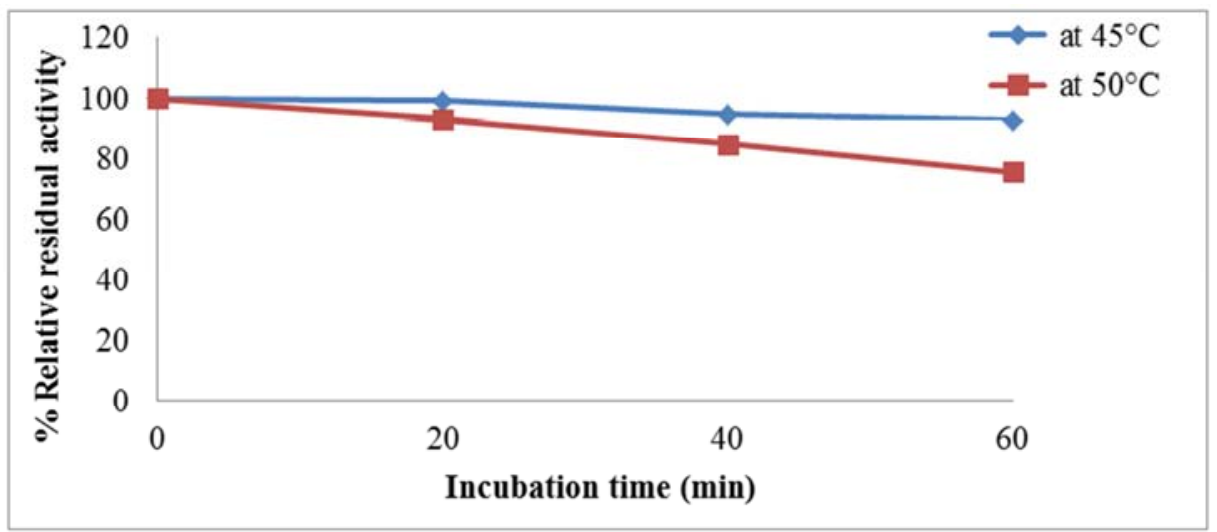

Figure 4. Effect of temperature on enzyme stability after 60 min incubation at 45 and $50^{\circ} \mathrm{C}$ for 20 min interval regularly.

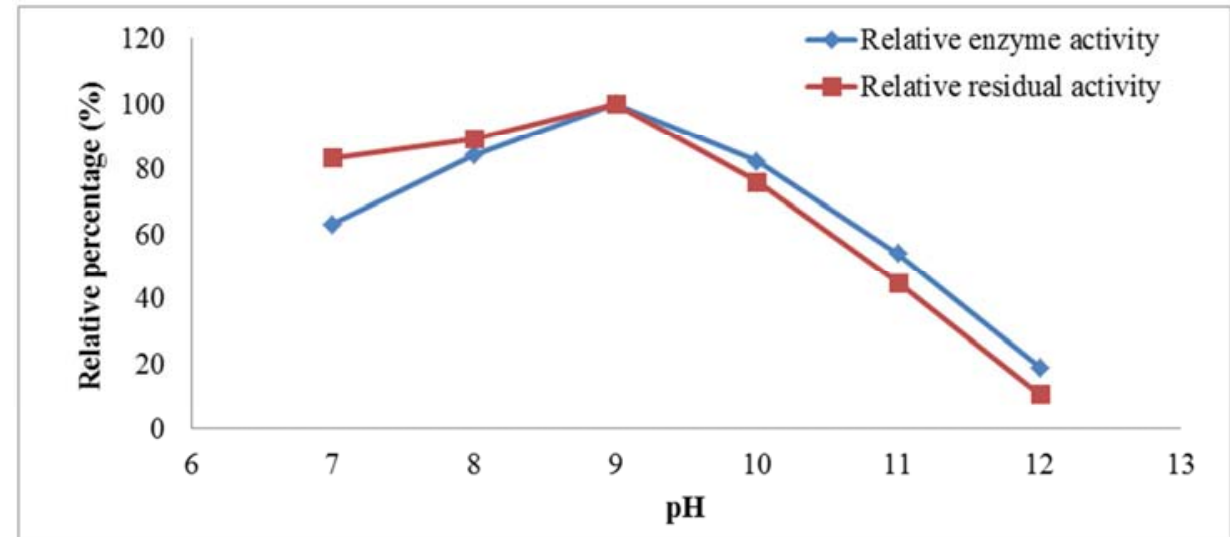

Figure 5. Effect of $\mathrm{pH}$ on enzyme activity (at $40^{\circ} \mathrm{C}$ for 30 min incubation) and stability (after 60 min pre-incubation in different $p H$ buffers at $30^{\circ} \mathrm{C}$ ) then assay was performed at $40^{\circ} \mathrm{C}$ and $\mathrm{pH} 9$. Activity of the enzyme pre-incubated at $\mathrm{pH} 9$ and assayed at same $\mathrm{pH}$ was considered as $100 \%$.

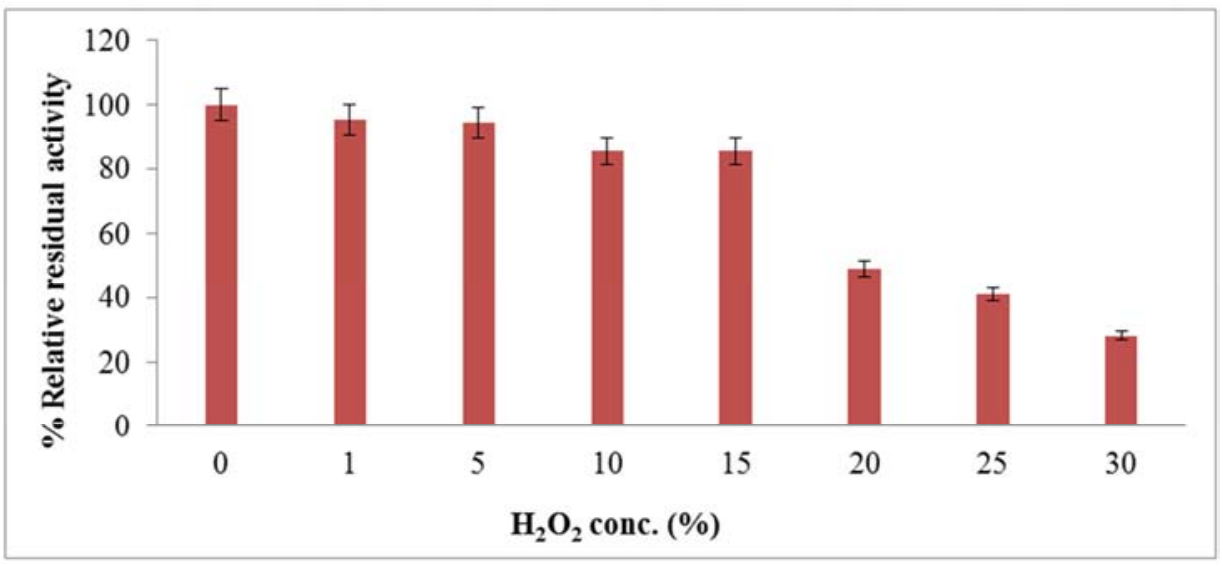

Figure 6. Effect of hydrogen peroxide on enzyme stability after preincubation for 60 min at $30^{\circ} \mathrm{C}$ following assay at $40^{\circ} \mathrm{C}$ and $\mathrm{pH}$ of 9 .

The enzyme was stable in a broad $\mathrm{pH}$ range, maintaining over 83 and $76 \%$ of its maximum activity at $\mathrm{pH} 7$ and 10 respectively (Figure 5). However, only 19\% of the maximum enzyme activity was retained at $\mathrm{pH} 12$.

\subsubsection{Effect of Oxidizing Agent $\left(\mathrm{H}_{2} \mathrm{O}_{2}\right)$ and Detergent on Enzyme Stability}

The enzyme retained $85.6 \%$ of its activity when preincubated in $15 \% \mathrm{H}_{2} \mathrm{O}_{2}$ for an hour. As the percentage of $\mathrm{H}_{2} \mathrm{O}_{2}$ increased the residual activity was decreased with $28 \%$ at $30 \% \mathrm{H}_{2} \mathrm{O}_{2}$ (Figure 6 ). The enzyme showed $72 \%$ of its activity after $1 \mathrm{~h}$ pre-incubation in $0.3 \%$ commercial detergent (Ariel).

\subsubsection{Effect of Metal Ions on Enzyme Activity}

The different cations tested at $0.01 \mathrm{M}$ concentration affected the enzyme activity differently. The activity was enhanced by $\mathrm{Mg}^{2+}(129 \%), \mathrm{Cu}^{2+}(113 \%)$ and $\mathrm{Mn}^{2+}(110 \%)$. It was inhibited by $\mathrm{Zn}^{2+}(65.6 \%), \mathrm{Hg}^{2+}(43.5 \%)$ and $\mathrm{Fe}^{2+}$ $(2.2 \%)$. However, $\mathrm{Ca}^{2+}$ did not affect the activity (Figure 7). 


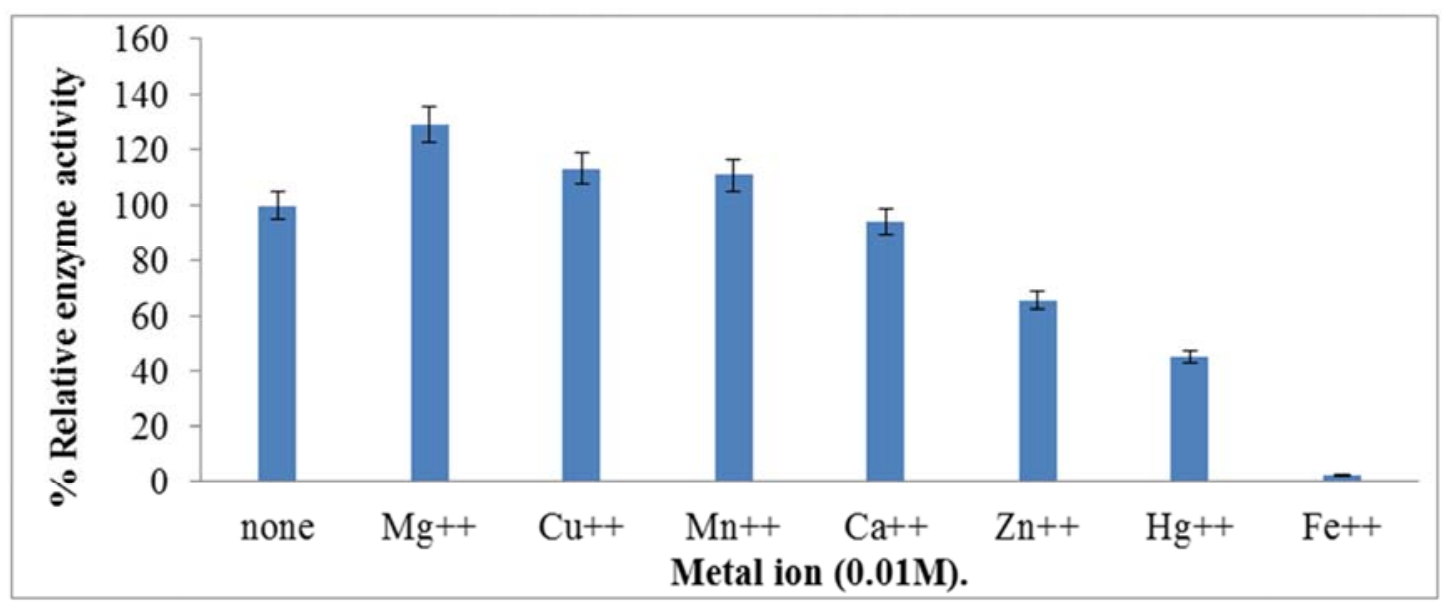

Figure 7. Effect of metal ions on enzyme activity for 30 min incubation at $40^{\circ} \mathrm{C}$ and $\mathrm{pH} 9$.

\subsection{Stain Removal Efficiency of Crude Enzyme}

The crude enzyme produced from Bacillus sp. Cab44 efficiently removed egg yolk stain in $40 \mathrm{~min}$. It took around 30 min to remove blood stain from cotton cloth (Figure 8 and 9).
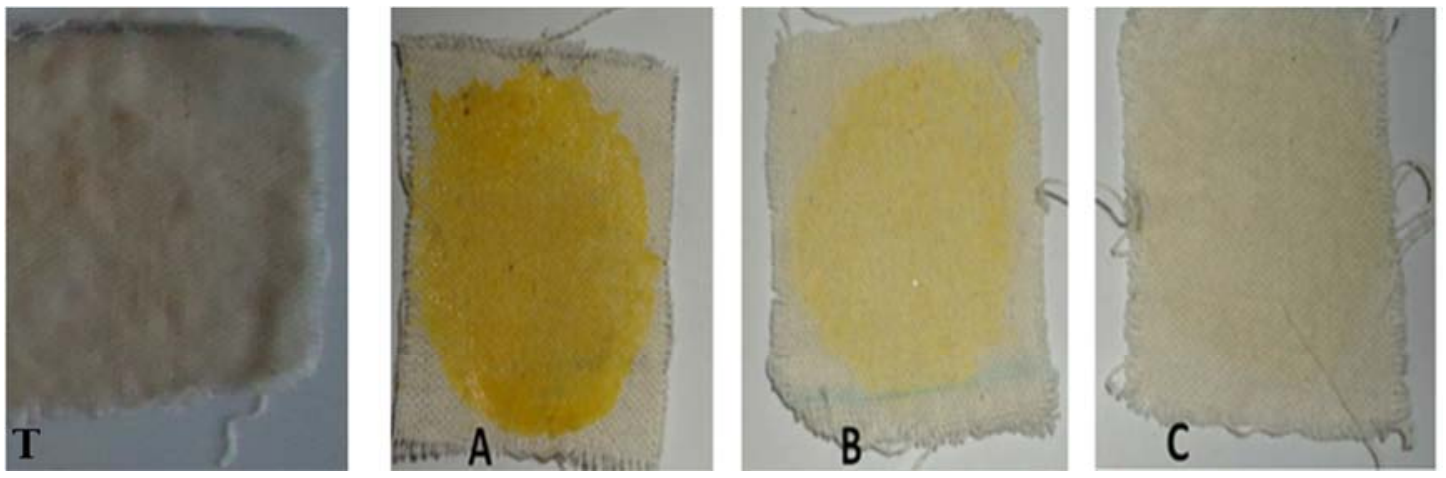

Figure 8. Egg yolk stain removal efficiency of enzyme produced by Bacillus sp. Cab44: (T) normal cotton Cloth; (A) Stained cotton fabric before reaction; (B) control ( $0 \%$ of enzyme/ only phosphate buffer); (C) with $5.07 \mathrm{U} / \mathrm{ml}$ of crude enzyme for $40 \mathrm{~min}$ at $40^{\circ} \mathrm{C}$ and $\mathrm{pH} 9$.
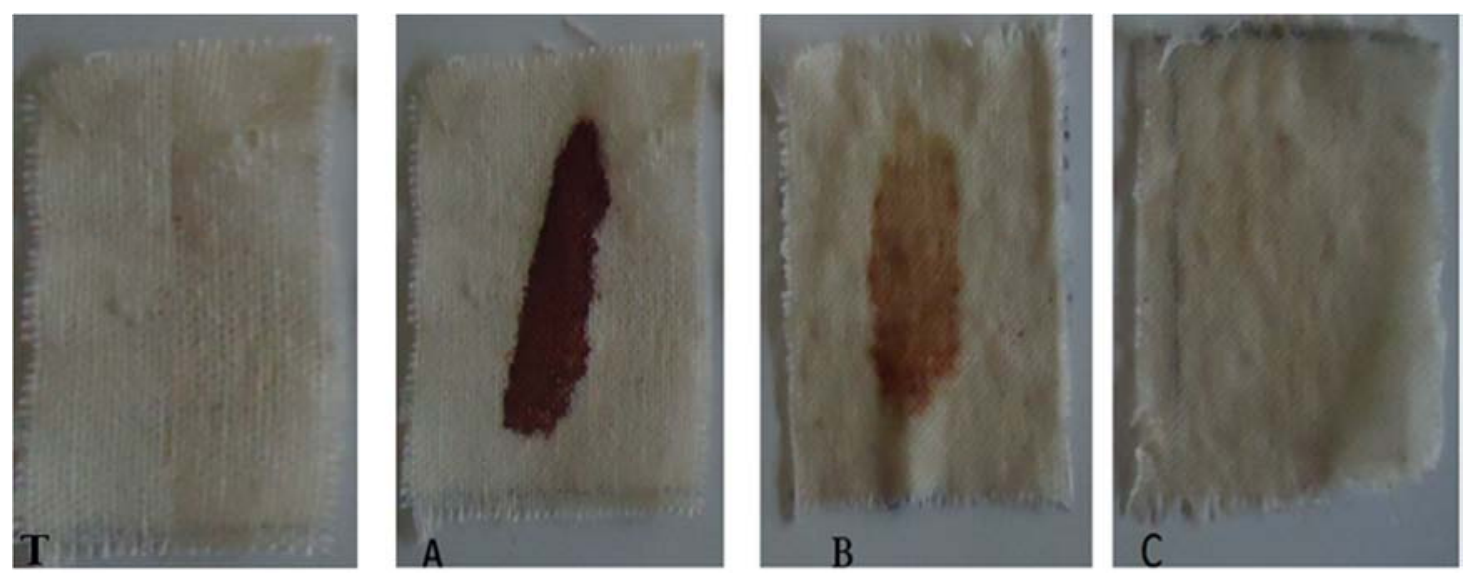

Figure 9. Blood stain removal efficiency of enzyme produced by Bacillus Sp TF44: (T) normal cotton Cloth; (A) Blood stained cotton fabric before reaction; (B) control ( $0 \%$ of enzyme, only phosphate buffer); (C) with $5.07 \mathrm{U} / \mathrm{ml}$ of crude enzyme for 30 min at $40^{\circ} \mathrm{C}$ and $\mathrm{pH} 9$.

\section{Discussion}

One of the main concerns of this study was to isolate and identify alkalophilic isolate having a vital ability to secrete extra-cellular proteolytic enzyme to be used for detergent additive. Accordingly, 188 bacterial strains were isolated from seven different areas. Formation of clear zone around the bacterial colony indicated the protease positive strains hydrolysed the skim milk present in the media (Figure 1). 
Five isolates were screened on the basis of clear zone size. Out of these, Bacillus sp. Cab44 exhibited high capability of removing egg yolk stain compared to others (Table 1). The use of alkaline skim milk agar for the isolation of alkaline protease producing bacteria has earlier been reported by some workers $[19,20]$. Results show that, Abaya Lake is rich in proteolytic bacteria. This indicates that Abaya Lake has potential for screening of bacterial strain which produce industrially important enzymes.

The crude enzyme produced from Bacillus sp. Cab44 was further characterized to evaluate its potential applications for formulation of detergent. It was optimally active between $\mathrm{pH}$ 7-10 and stable at alkaline $\mathrm{pH}$. Proteases active in the $\mathrm{pH}$ range of 8-12 and stable at alkaline $\mathrm{pH}$ are known as potential candidates for detergent application. This indicates that protease produced from Bacillus sp. Cab44 has a good potential for such applications [21, 22, 23, 24].

Another interesting property of the protease produced from Bacillus sp. Cab44 was its ability to maintain more than $75 \%$ of its maximum activity after pre-incubation at its optimum temperature $\left(50^{\circ} \mathrm{C}\right)$ for $60 \mathrm{~min}$. The studies on temperature profile of the enzyme showed an optimum temperature range between $40-60^{\circ} \mathrm{C}$ with maximal activity at $50^{\circ} \mathrm{C}$ (Figure 3 ). The physiochemical characterization of the protease indicates its suitability as a potential additive in detergents [18, 19, 23, 24]. These observations were also equivalent to that had been found by Jabeen and Qazi (2011) [25]. Maximum activity of protease produced from Bacillus sp. Cab44 at high $\mathrm{pH}$ (9) and temperature of $50^{\circ} \mathrm{C}$ indicates its high potential of industrial employment in hard wash condition.

The stability and compatibility of produced enzyme with oxidizing agent is an important factor to be used as detergent additive. Detergents contain oxidizing agents, which may hinder the activity of certain enzymes and hence enzyme stable with oxidizing agents are required for detergent industry. The protease produced from the isolate lost little or no enzyme activity on treatment with $15 \% \mathrm{H}_{2} \mathrm{O}_{2}$ for one hour. This shows that the protease produced from the isolate is compatible with and stable in oxidizing agents [26].

Identification of appropriate metal ions for activity and thermo stability to the enzymes are very important for their applications at commercial levels [27]. Among the tested metal ions $\mathrm{Mg}^{+2}$ is potent inducer of the protease activity as shown in Figure 7. On the other hand $\mathrm{Hg}^{+2}$ and $\mathrm{Fe}^{+2}$ are the potent inhibitors of enzymatic activity produced from Bacillus sp. Cab44. Maximum loss of enzymatic activity was observed in $\mathrm{Fe}^{+2}$. The presence of $\mathrm{Ca}^{2+}$ did not affect the enzyme activity [28]. However, in another report, metal ions like $\mathrm{Mn}^{2+}$ and $\mathrm{Ca}^{2+}$ were found to be potent enhancers [29].

In the present investigation (shown in Figure 8 and 9) the protease produced from Bacillus sp. Cab44 had high capability of removing blood and egg yolk stains. Interestingly, the stain removal process was accomplished without any commercial detergent additives. This makes the protease advantageous for use as detergent additive against a wide variety of stains like blood, egg yolk and other body secretions from cloths. Also it was compatible with all surfactants found in commercial detergent (Ariel), which indicates its potential candidate in detergent formulation. This result is well established by many authors [25, 28, 30]. Such practice may find application in removing blood stains from materials of medical importance. The result is far better comparable to the earlier reports of protease from Pseudomonas aeruginosa [9] and Bacillus licheniformis U1 [18].

The enzyme used in this study has the ability to completely remove blood and egg yolk stains within $40 \mathrm{~min}$ at $40^{\circ} \mathrm{C}$ at $5.07 \mathrm{U} / \mathrm{ml}$, unlike the protease that was used to remove egg yolk stain from test fabric which needed $2 \mathrm{~h}$ for complete egg yolk stain removal at $40^{\circ} \mathrm{C}$ and much higher enzyme concentration $(100 \mathrm{U} / \mathrm{ml})$ [31].

The exploration of protease producing bacteria is still underway to achieve high quality industrial grade enzyme to produce goods [32]. The use of microorganisms to produce enzymes has a number of technical and economic advantages and in recent years it has become the predominant mode of enzyme production $[33,34]$.

\section{Conclusions}

As the method in this investigation, the accomplishment of stain removal process with a minimum time requirement indicates that this enzyme is highly cost effective candidate for enzyme incorporation in detergent formulations. In addition removal of stain from cloths undergoes the process without any additive of detergent or chemicals. These indicate the enzymes produced in this investigation have potential application in stain removal of medical materials.

\section{Acknowledgements}

The author wish to thank Ato Zerihun Senbeto for his financial support for publication of this research paper. Also the author would like to thank to Zemzem Ayele, Haniza Redwan and Omer Abrar for their supports.

\section{References}

[1] Rao, M. B., Tanksale, A. M., Ghatge, M. S. and Deshpande, V. V. (1998). Molecular and biotechnological aspects of microbial proteases. Microbiology and Molecular Biology. Research, 62:597-635.

[2] Saperas, N. and Subir, F. E. (2011). Proteolytic enzymes in detergents: evidence of their presence through activity measurements based on electrophoresis. Journal of Chemistry, 88:1702-1706.

[3] Gupta, R., Beg, Q. K. and Lorenz, P. (2002). Bacterial alkaline proteases: molecular approaches and industrial applications. Applied Microbial Biotechnology, 59:15-32.

[4] Saha, M. L., Begum, K. J. M. H., Khan, M. R. and Gomes, D. J. (2011). Bacteria associated with the tannery effluent and their alkaline protease activities. Plant Tissue Culture Biotechnology, 21:53-61. 
[5] Younes, G., Sara, R., Alireza, E., Aboozar, K., Maryam, S. and Najme, T. (2011). Screening and isolation of extracellular protease producing bacteria from the Maharloo Salt Lake. Iranian Journal of Pharmaceutical Sciences, 7:175-180.

[6] Vadlamani, S. and Parcha, S. R. (2011). Studies on industrially important alkaline protease production from locally isolated superior microbial strain from soil microorganisms. International Journal of Biotechnology Applications, 3:102105.

[7] Kumar, D., Savitri, T., Verma, R. and Bhalla, T. C. (2008). Microbial proteases and application as laundry detergent additive. Research Journal of Microbiology, 3:661-672.

[8] Rajkumar, R., Jayappriyan, R. K. and Rengasamy, R. (2011). Purification and characterization of a protease produced by Bacillus megaterium RRM2: application in detergent and dehairing industries. Journal of Basic Microbiology, 51:614624.

[9] Najafi, M. F. (2005). Potential application of protease isolated from Pseudomonas aeruginosa PD100. Electronic Journal of Biotechnology, 8:197-203.

[10] Raj, A., Khess, N., Pujari, N., Bhattacharya, S., Das, A. and Rajan, S. S. (2012). Enhancement of protease production by Pseudomonas aeruginosa isolated from dairy effluent sludge and determination of its fibrinolytic potential. Asian Pacific Journal of Tropical Biomedicine, 3:1845-1851.

[11] Chaudhari, S. G., Chaudhari, S. D., Khobragade, R. M. and Deshmukh, A. M. (2013). Studies on production of alkaline proteases from Bacillus species and its application in detergent industry. Dav International Journal of Science, 2:44-48.

[12] Bayoumi, R. A., Atta, M. H., Swelam, S. M. and El-Hemiany, A. (2010). Microbial production of thermo alkaliphilic enzymes for application in biodetergent technology. European Journal of Applied Sciences, 2:85-93.

[13] Prabhavathy, G., Rajasekara, M. P. and Senthilkumar, B. (2013). Identification of industrially important alkaline protease producing Bacillus subtilis by 16s rRNA sequence analysis and its applications. International Journal of Research in Pharmaceutical and Biomedical Sciences, 4:332-338.

[14] Das, G. and Prasad, M. P. (2010). Isolation, purification \& mass production of protease enzyme from Bacillus subtilis. International Research Journals of Microbiology, 1:26-31.

[15] Gaur, S., Agrahari, S. and Wadhwa, N. (2010). Purification of protease from Pseudomonas thermaerum GW1 isolated from poultry waste site. The Open Microbiology Journal, 4:67-74.

[16] Padmapriya, B., Rajeswari, T., Nandran, R. and Raj, F. (2012). Production and purification of alkaline serine protease from marine Bacillus species and its application in detergent industry. European Journal of Applied Sciences, 4:21-26.

[17] Pathak, A. P. and Deshmukh, K. B. (2012). Alkaline protease production, extraction and characterization from alkaliphilic Bacillus licheniformis KBDL4: A Lonar Soda Lake isolate. Indian Journal of Experimental Biology, 50:569-576.

[18] Pravin, D., Sunil, B., Anjana, G. and Bhatt, S. (2014). Isolation, characterization and investigating the industrial applications of thermostable and solvent tolerant serine protease from hot spring isolated thermophililic Bacillus licheniformis U1. International Journal of Applied Science and Biotechnology, 2:75-82.

[19] Boominadhan, U., Rajakumar, R., Karrpaga, P. V. S. and Joe, M. M. (2009). Optimization of protease enzyme production using Bacillus sp. Isolated from different wastes. Botany Research International, 2:83-87.

[20] Haile, G. and Gessesse, A. (2012). Properties of alkaline protease $\mathrm{C} 45$ produced by alkaliphilic Bacillus $s p$. isolated from Chitu, Ethiopian Soda Lake. Journal of Biotechnology and Biomatter, 2: 1-4.

[21] Rao, K. and Narasu, L. M. (2007). Alkaline protease from Bacillus firmus 7728. African Journal of Biotechnology, 6:2493-2496.

[22] Sepahy, A. A. and Jabalameli, J. (2011). Effect of culture conditions on the production of an extracellular protease by Bacillus sp. isolated from soil sample of Lavizan Jungle Park. SAGE-Hindawi Access to Research Enzyme Research, 1:1-7.

[23] Verma, T. and Baiswar, V. (2013). Isolation and characterization of extracellular thermoalkaline protease producing Bacillus cereus isolated from tannery effluent. The International Journal of Engineering and Science, 2:23-29.

[24] Vijayaraghavan, P., Lazarus, S. and Gnana, S. P. V. (2013). De-hairing protease production by an isolated Bacillus cereus strain AT under solid-state fermentation using cow dung: biosynthesis and properties. Saudi Journal of Biological Sciences, 1:1-8.

[25] Jabeen, F. and Qazi, J. I. (2011). Production and optimization of detergent compatible thermostable alkaline protease from Bacillus cereus FJ10. Journal of Scientific and Industrial Research, 70:1042-1048.

[26] Chu, W. H. (2007). Optimization of extracellular alkaline protease production from species of Bacillus. Journal of Indian Microbiology and Biotechnology, 34:241-245.

[27] Nadeem, M., Qazi, J. I., Baig, S. and Syed, Q. (2007). Studies on commercially important alkaline protease from Bacillus Lichniformis $\mathrm{N}-2$ isolated from decaying organic soil. Turkish Journal of Biochemistry, 32:171-177.

[28] Rajkumar, R., Jayappriyan, R. K. and Rengasamy, R. (2011). Purification and characterization of a protease produced by Bacillus megaterium RRM2: application in detergent and dehairing industries. Journal of Basic Microbiology, 51:614 624.

[29] Siddalingeshwara, K. G., Uday, J., Huchesh, C. H., Puttaraju, H. P., Karthic, J., Sudipta, K. M., Pramod, T. and Vishwanatha, T. (2010). Screening and characterization of protease from Bacillus sp. International Journal of Applied Biology and Pharmaceutical Technology, 1:575-581.

[30] Hema, T. A. and Shiny, M. (2012). Production of protease enzyme from Bacillus clausii Sm3. Journal of Pharmacy and Biological Science, 1:1-37.

[31] Kumar, D. and Bhalla, T. C. (2004). Bacillus sp. APR-4 protease as a laundary additive. Indian Journal of Biotechnology, 3:563-567.

[32] Priya, V. V. G., Preethi, S., Karthikeyan, S. and Babu, R. N. G. (2016). Isolation and identification of protease producing bacteria from soil. International Journal of Research in Engineering and Technology, 3 (8):1362-1365. 
[33] Singh, P., Rani, A. and Chaudhary, N. (2015). Isolation and characterization of protease producing Bacillus sp from soil. International Journal of Pharma Sciences and Research, 6 (4):633-639.
[34] Harish R. and Chauhan, B. J. (2017). Isolation, characterization of protease producing microbes from soil of agriculture land and purification of protease. International Journal of Pharma Research and Health Sciences, 5 (1):15811585. 